\title{
Anti-emetic drugs in oncology: pharmacology and individualization by pharmacogenetics
}

\author{
D. A. Perwitasari - Hans Gelderblom · Jarir Atthobari • \\ Mustofa Mustofa • Iwan Dwiprahasto • \\ Johan W. R. Nortier · Henk-Jan Guchelaar
}

Received: 24 June 2010/ Accepted: 9 November 2010/Published online: 28 January 2011

(C) The Author(s) 2011. This article is published with open access at Springerlink.com

\begin{abstract}
Objective Nausea and vomiting are the most distressful side effects of cytotoxic drugs in cancer patients. Antiemetics are commonly used to reduce these side effects. However, the current antiemetic efficacy is about $70-80 \%$ in patients treated with highly-emetogenic cytotoxic drugs. One of the potential factors explaining this suboptimal response is variability in genes encoding enzymes and proteins which play a role in metabolism, transport and receptors related to antiemetic drugs. Aim of this review was to describe the pharmacology and pharmacogenetic concepts of of antiemetics in oncology. Method Pharmacogenetic and pharmacology studies of antiemetics in oncology published between January 1997 and February 2010 were searched in PubMed. Furthermore, related textbooks were also used for exploring the pharmacology of antiemetic drugs. The antiemetic drugs which were searched were the 5-hydroxytryptamine 3 receptor
\end{abstract}

D. A. Perwitasari

Department of Pharmacy, Ahmad Dahlan University,

Yogyakarta, Indonesia

D. A. Perwitasari

Medical Faculty, Gadjah Mada University, Yogyakarta, Indonesia

H. Gelderblom · J. W. R. Nortier

Department of Clinical Oncology, Leiden University Medical

Center, Leiden, The Netherlands

J. Atthobari - M. Mustofa - I. Dwiprahasto

Department of Pharmacology and Therapy, Medical Faculty,

Gadjah Mada University, Yogyakarta, Indonesia

H.-J. Guchelaar $(\square)$

Department of Clinical Pharmacy and Toxicology, Leiden

University Medical Center, PO Box 9600, 2300 RC Leiden,

The Netherlands

e-mail: h.j.guchelaar@lumc.nl antagonists (5-HT3RAs), dopamine antagonists, corticosteroids, benzodiazepines, cannabinoids, antihistamines and neurokinin-1 antagonists. Result The 5-HT3RAs are widely used in highly emetogenic chemotherapy in combination with dexamethasone and a neurokinin-1 antagonist, especially in acute phase. However, the dopamine antagonists and benzodiazepines were found more appropriate for use in breakthrough and anticipatory symptoms or in preventing the delayed phase of chemotherapy induced nausea and vomiting. The use of cannabinoids and antihistamines need further investigation. Only six articles on pharmacogenetics of the 5-HT3RAs in highly emetogenic chemotherapy are published. Specifically, these studies investigated the association of the efficacy of 5-HT3RAs and variants in the multi drug resistance 1 (MDR1) gene, 5-HT3A,B and C receptor genes and CYP2D6 gene. The pharmacogenetic studies of the other antiemetics were not found in this review. Conclusion It is concluded that pharmacogenetic studies with antiemetics are sparse. It is too early to implement results of pharmacogenetic association studies of antiemetic drugs in clinical practice: confirmation of early findings is required.

Keywords Anti-emetic agents - Cancer .

Pharmacogenetics · Pharmacology

\section{Impact of findings on practice}

- Since only limited pharmacogenetic studies on antiemetic drugs in oncology are known, the clinician's decision regarding antiemetic treatment are currently based on patient's risk factors and emetogenicity of chemotherapeutic drugs rather than on genetic variants affecting antiemetic drug reponse. 
- Genetic variants should only be considered in case of suboptimal antiemetic response in patients treated with highly emetogenic chemotherapy.

- Other investigators may be encouraged to conduct pharmacogenetic studies on antiemetic drug treatment in oncology.

\section{Introduction}

Chemotherapy induced nausea and vomiting (CINV) are the most distressing side effects in cancer patients treated with chemotherapy and can have a negative impact on the patients' quality of life [1]. Moreover, CINV can seriously influence patients' adherence to chemotherapy [2] and may thus influence progression free survival and overall survival. In the past, before using standard anti-emetic drug regimens, nausea and vomiting resulted in up to $20 \%$ of patients in delay or refusal of chemotherapy [3]. Highly effective anti-emetic drugs are available nowadays and their standardized use increases patients' quality of life [4]. However, in patients receiving highly-emetogenic cytotoxic drug therapy the proportion of patients experiencing effective anti-emetic therapy is only 70-80\% [5]. One of the factors responsible for variable response to anti-emetic drugs is the inter-individual difference in biotransformation. Moreover, polymorphisms in genes encoding drug receptors related to the anti-emetic drugs along with other patient related risk factors such as gender, age, and drug related factors such as emetogenic potential of chemotherapy may explain inter-individual differences in antiemetic drug response [6].

\section{Objective}

The aim of this paper is to review the mechanism of action and pharmacology and the potential role of pharmacogenetics of anti-emetic drugs in oncology.

\section{Methods}

Studies on the pharmacology and pharmacogenetics of the 5-hydroxytryptamine 3 receptor antagonists (5-HT3RAs), dopamine antagonists, corticosteroids, benzodiazepines, cannabinoids, antihistamines and neurokinin-1 antagonists were searched in PubMed January 1997 to February 2010. In addition, pharmacology textbooks were also reviewed to summarize the mechanism and pharmacological effects of antiemetics.

\section{Result}

Pharmacogenetic studies of antiemetics in oncology are scarce and the individual studies are relatively small: in four studies more than 200 patients, in one study 120 patients and in one study 70 patients were included. These studies investigated the pharmacogenetics of 5-HT3RAs in Multi Drug Resistence1 (MDR1) gene, 5-HT3 A,B and C receptor genes and the CYP2D6 gene. The summary of these studies is listed in Table 1. Furthermore, more articles related with mechanism and pharmacologicy effect were found in this review. The mechanism of antiemetics are listed in Fig. 1. The mechanism and pharmacology effect of antiemetics will be discussed below.

\section{Discussion}

Chemotherapy induced nausea and vomiting (CINV)

Based on the emetogenic potential, cytotoxic drugs are classified into several categories: (1) highly-emetogenic, which can cause symptoms in $>90 \%$ patients without anti-emetic drug treatment, (2) moderate risk, which can cause symptoms in $30-90 \%$ of patients (3) low risk with $10-30 \%$ of symptomatic patients and (4) minimally emetogenic with $<10 \%$ of symptomatic patients. Table 2 lists the emetogenic categories for various chemotherapeutic agents [7].

Emetogenicity includes both onset and duration of nausea and vomiting [2]. In patients receiving a combination of cytotoxic drugs, the classification of emetogenicity is based on the cytotoxic drug with the greatest emetogenic potential [8]. Specifically, for defining the emetogenicity of combination regimens of cytotoxic drugs which required a more intensive antiemetic prophylaxis and therapy, the following situations may occur: (1) the minimal emetogenic agent does not contribute to the emetogenicity of the combined regimen, (2) the low emetogenic agents will increase the emetogenicity of the combined regimen by one level greater than the most emetogenic agent in the regimen, (3) the moderately and highly emetogenic agents will increase the emetogenicity of each drug in the combined regimen by one level [9], e.g. combination of doxorubicin and cyclophosphamide are highly emetogenic, although both drugs alone are classified as moderate.

$\mathrm{CINV}$ is categorized as acute (occurring within $24 \mathrm{~h}$ of therapy], delayed (persisting for 6-7 days after therapy) or anticipatory (occurring prior to chemotherapy administration). Breakthrough nausea and vomiting refer to uncontrollable symptoms and need rescue anti-emetics despite the use of prophylactic anti-emetics. Some patients also 
Table 1 Pharmacogenetic studies of anti-emetics

\begin{tabular}{|c|c|c|c|c|}
\hline $\begin{array}{l}\text { Drugs target (author, year of } \\
\text { publication) }\end{array}$ & Gene & Endpoint & $\mathrm{N}$ & Results \\
\hline $\begin{array}{l}\text { Ondansetron or tropisetron } \\
\text { Kaiser et al. (2002), [20] }\end{array}$ & CYP2D6 & $\begin{array}{l}\text { Nausea and vomiting on highly } \\
\text { emetogenic cytotoxic drug }\end{array}$ & 270 & $\begin{array}{l}\text { UMs demonstrate the highest incidence and severity } \\
\text { of nausea and vomiting. Frequency of UMs was } \\
1.5 \% \text {. }\end{array}$ \\
\hline $\begin{array}{l}\text { Ondansetron or tropisetron } \\
\text { Tremblay et al. (2003), [52] }\end{array}$ & $\begin{array}{l}\text { 5-HT3B } \\
\text { receptor }\end{array}$ & $\begin{array}{l}\text { Nausea and vomiting on high } \\
\text { emetogenic cytotoxic drug }\end{array}$ & 286 & $\begin{array}{l}\text { 5-HT3B receptor gene may serve as genetic } \\
\text { predictor for anti-emetic therapy with the _AAG } \\
\text { deletion variant }(\mathrm{OR}=32) \text { after adjusted with } \\
\text { other risk factors of emesis. }\end{array}$ \\
\hline $\begin{array}{l}\text { Tropisetron } \\
\text { Kaiser et al. (2004), [6] }\end{array}$ & $\begin{array}{l}5 \text {-HT3A } \\
\text { receptor }\end{array}$ & $\begin{array}{l}\text { Nausea and vomiting on high } \\
\text { emetogenic cytotoxic drug }\end{array}$ & 242 & $\begin{array}{l}\text { There were } 21 \text { polymorphisms in 5-HT3A receptor } \\
\text { gene, whereas the } 15 \text { polymorphisms had partial } \\
\text { linkage each of them. The haplotypes in these } \\
\text { genes did not have significant association with } \\
\text { chemotherapy induced nausea and vomiting. }\end{array}$ \\
\hline $\begin{array}{l}\text { Tropisetron, granisetron, } \\
\text { ondansetron. } \\
\text { Babaoglu et al. (2005), [57] }\end{array}$ & $\begin{array}{l}\mathrm{ABCB} 1 \\
(\mathrm{MDR} 1)\end{array}$ & $\begin{array}{l}\text { Nausea and vomiting on high } \\
\text { emetogenic cytotoxic drug }\end{array}$ & 216 & $\begin{array}{l}\text { The complete control rate of nausea and vomiting } \\
\text { was higher in subjects with ABCB1 TT genotype } \\
\text { as compared with those with TC or CC genotype } \\
\text { ( } 92.9 \% \text { vs. } 56.1 \% \text { vs. } 47.6 \%, P=0.044)\end{array}$ \\
\hline $\begin{array}{l}\text { Ondansetron } \\
\text { Fasching et al. (2008), [54] }\end{array}$ & $\begin{array}{l}\text { 5-HT3C } \\
\text { receptor }\end{array}$ & $\begin{array}{l}\text { Nausea and vomiting on moderate } \\
\text { emetogenic cytotoxic drug }\end{array}$ & 120 & $\begin{array}{l}\text { Variant genotype of } \mathrm{K} 163 \mathrm{~N} \text { was associated with } \\
\text { vomiting }(\mathrm{RR}=2.62)\end{array}$ \\
\hline $\begin{array}{l}\text { Dolasetron or tropisetron } \\
\text { Ward et al. (2008), [53] }\end{array}$ & $\begin{array}{l}\text { 5-HT3C } \\
\text { receptor }\end{array}$ & $\begin{array}{l}\text { Nausea and vomiting on high } \\
\text { emetogenic cytotoxic drug }\end{array}$ & 70 & $\begin{array}{l}\text { 5-HT3C receptor gene may not serve as genetic } \\
\text { predictor for anti-emetic therapy }\end{array}$ \\
\hline
\end{tabular}

UMs: Ultra-rapid metabolizers

5-HT3A: 5-Hydroxytriptamine 3A

5-HT3B: 5-Hydroxytriptamine 3B

5-HT3C: 5-Hydroxytriptamine 3C

ABCB1: ATP Binding Casette, subfamily B, member 1

MDR1: Multi-Drug Resistence 1

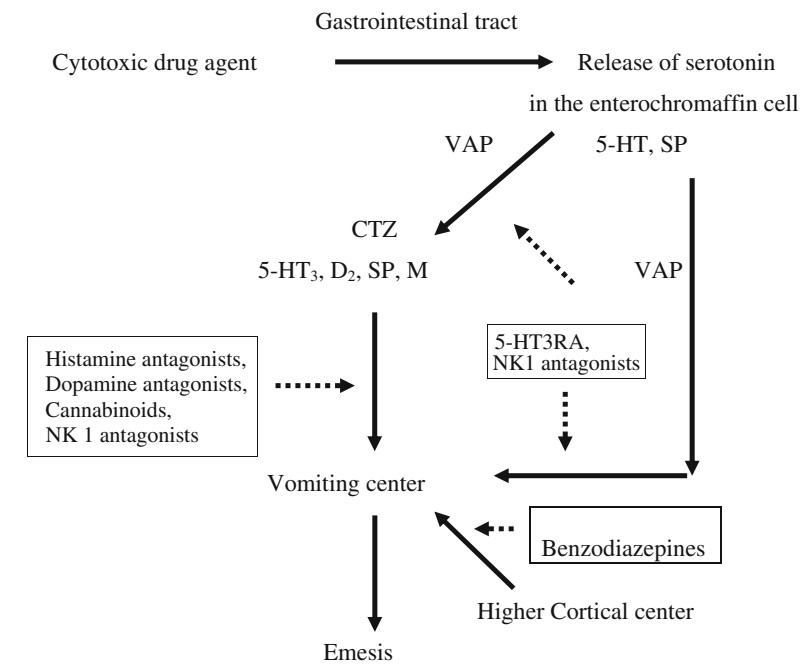

Fig. 1 Activation of emetic pathway by cytotoxic drugs and site of action of ant-emetic drugs. Adapted from [10, 26, 58]. 5-HT 5 Hydroxytriptamin, $D_{2}$ dopamine, $S P$ substance $\mathrm{P}, H$ histamine, $M$ muscarinic, $C T Z$ chemoreceptor trigger zone, VAP vagal afferent pathway, 5-HT3RA 5-HT3 receptor antagonist. Emesis pathway solid arrow. Sites of action of drugs dotted arrow

experience refractory nausea and vomiting when they did not receive adequate control of nausea and vomiting in prior cycles [2].
Cytotoxic drugs can cause emesis through stimulation in the neuron-anatomical centers: (1) the emetic center, (2) the area postrema or chemoreceptor trigger zone (CTZ), and (3) the vagal nerve afferents [10]. The CTZ is sensitive to chemical stimuli, and is the main site of action of anti-emetic drugs [11]. However, the bloodbrain barrier which is closely located to the CTZ is permeable allowing circulating mediators to act directly to the emetic center [11]. However, newer insight from animal studies suggest that an anatomically discrete vomiting center is unlikely to exist. Rather, a number of loosely organized neuronal areas within the medulla probably interact to coordinate the emetic reflex. The neurons coordinating the complex series of events that occur during emesis have been termed the "central pattern generator." Also, free radical formation appear to have an important role in the induction of nausea and vomiting [12]. The most important neurotransmitters which involve in emetic process are dopamine, serotonin and substance $\mathrm{P}$. However, the receptors 5-HT1A, 2A, $2 \mathrm{C}, 3 \mathrm{~A}, 3 \mathrm{~B}, 4$, receptors $\mathrm{CB} 1$ and $\alpha$ adrenergic are also known to be involved in emesis mechanism [13]. Moreover, $\mu$-opioid receptors are also thought to be involved in mediating anti-emetic effect in humans [14]. 
Table 2 Emetogenicity of chemotherapeutic agents (Adapted from [7])

\begin{tabular}{|c|c|c|}
\hline Emetogenic potential & Cytotoxic drug & Dosage \\
\hline High & $\begin{array}{l}\text { Cisplatin } \\
\text { Cyclophosphamide } \\
\text { Dacarbazine } \\
\text { Mechloretamine } \\
\text { Carmustine } \\
\text { Streptozotocin }\end{array}$ & $>1,500 \mathrm{mg} / \mathrm{m}^{2}$ \\
\hline Moderate & $\begin{array}{l}\text { Cyclophosphamide } \\
\text { Carboplatin } \\
\text { Doxorubicin }\end{array}$ & $<1,500 \mathrm{mg} / \mathrm{m}^{2}$ \\
\hline & $\begin{array}{l}\text { Cytarabine } \\
\text { Oxaliplatin } \\
\text { Ifosfamide } \\
\text { Daunorubicin } \\
\text { Epirubicin } \\
\text { Idarubicin } \\
\text { Irinotecan }\end{array}$ & $>1,000 \mathrm{mg} / \mathrm{m}^{2}$ \\
\hline Low & $\begin{array}{l}\text { Paclitaxel } \\
\text { Docetaxel } \\
\text { Mitoxantrone } \\
\text { Topotecan } \\
\text { Etoposide } \\
\text { Pemetrexed } \\
\text { Methotrexate } \\
\text { Mitomycin }\end{array}$ & \\
\hline & $\begin{array}{l}\text { Gemcitabine } \\
\text { Cytarabine } \\
\text { 5-Fluorouracil } \\
\text { Bortezomib } \\
\text { Cetuximab } \\
\text { Trastuzumab }\end{array}$ & $>1,000 \mathrm{mg} / \mathrm{m}^{2}$ \\
\hline Minimal & $\begin{array}{l}\text { Bleomycin } \\
\text { Busulfan } \\
\text { 2-Chlorodeoxyadenosine } \\
\text { Fludarabine } \\
\text { Vinblastine } \\
\text { Vincristine } \\
\text { Vinorelbine } \\
\text { Bevacizumab }\end{array}$ & \\
\hline
\end{tabular}

The majority of dopamine, serotonin and substance $\mathrm{P}$ receptors are found in the dorsal vagal complex, the area postrema and in the gastrointestinal tract. After cytotoxic drugs have passed through the blood stream to the gastrointestinal tract, they can cause damage to the enterochromaffin cells. This damage causes subsequent release of 5-HT3 and stimulates the CTZ and vomiting center via 5HT3 receptors. Ultimately, this causes contraction of abdominal muscles, diaphragm, stomach and esophagus activation and an emetic response [10]. The mechanism of CINV is depicted in Fig. 1.

5-HT3 receptors are located centrally in the CTZ of the area postrema and peripherally in the vagal nerve terminals. Activation of the vomiting center is caused by direct stimulation of 5-HT3 receptors in the CTZ by cytotoxic drugs. Equally, stimulation of vagal afferents will be transmitted to the vomiting center through nucleus tractus solitarius [15]. Five different 5-HT3 receptors are known in humans, 5-HT3A, B, C, D and E. 5-HTR3A, 5-HTR3B and 5-HTR3C are expressed in the CNS as well as in the vagal nerve terminals, whereas 5-HTR3D is predominantly and 5-HTR3E is exclusively expressed in the gastrointestinal tract. The 5-HT3A and 5-HT3B receptor may be involved in the mechanism of CINV [16].

Delayed and acute emesis mechanism are thought to be different. Acute emesis is mainly stimulated by serotonin whereas dopamine and histamine are thought to contribute to delayed emesis. Some inflammation mediators, such as prostaglandine, histamine and substance $\mathrm{P}$ are involved in visceral inflammation which results in delayed emesis [10]. Otherwise, the Positron Emesis Tomography (PET), could be also useful to investigate the future pathophysiology of nausea and vomiting, especially in delayed emesis, refractory emesis and emesis during multiple cycles of chemotherapy [17].

Pharmacology of anti-emetic drugs

\section{5-Hydroxytryptamine 3 receptor antagonists [5-HT3RAs]}

The 5-HT3RAs are the standard anti-emetic treatment for acute CINV in patients treated with moderately to highly emetogenic chemotherapy. It has been demonstrated that their use in combination with a corticosteroid results in complete protection of acute CINV in $70-80 \%$ of patients receiving highly emetogenic chemotherapy $[18,19]$. The 5-HT3RAs bind selectively and competitively to 5-HT3 receptors thereby blocking the emetogenic signals to the vomiting center [15].

Several 5-HT3RAs, such as dolasetron, granisetron, ondansetron, tropisetron and palonosetron are available [16]. Table 3 shows the pharmacological characteristics of these 5-HT3RAs.

Generally, the 5-HT3RAs are well absorbed from the gastrointestinal tract and undergo first-pass metabolism after oral administration. The prodrug dolasetron is rapidly metabolized by carbonyl reductase to its active form, hydrodolasetron which is $70 \%$ bound to plasma proteins. This active metabolite is further metabolized mainly by cytochrome P450 [CYP] 2D6 [15].

Granisetron is metabolized by the liver through $\mathrm{N}$-demethylation, aromatic ring oxidation, and conjugation 
Table 3 Pharmacokinetic characteristics of 5-HT3 receptor antagonists. Adapted from [13, 20, 49, 59]

\begin{tabular}{|c|c|c|c|c|c|}
\hline & Ondansetron & Dolasetron & Granisetron & Tropisetron & Palonosetron \\
\hline Oral bioavailability & $60-70 \%$ & $76 \%$ & $60 \%$ & $60 \%$ & $97 \%$ \\
\hline Volume of distribution & $1.8 \mathrm{~L} / \mathrm{kg}$ & $5.8 \mathrm{~L} / \mathrm{kg}$ & $3.0 \mathrm{~L} / \mathrm{kg}$ & $5.7-8.6 \mathrm{~L} / \mathrm{kg}$ & $8.3 \mathrm{~L} / \mathrm{kg}$ \\
\hline \multirow[t]{4}{*}{ Metabolism } & CYP1A $1^{\mathrm{a}}$ & CYP2D6 & CYP3A4/5 & CYP2D6 & CYP2D6 \\
\hline & CYP1A2 & CYP3A/4/5 & CYP1A1 & CYP3A $/ 4 / 5^{\mathrm{a}}$ & CYP1A2 ${ }^{\mathrm{a}}$ \\
\hline & CYP2D6 & & & & CYP3A $/ 4 / 5^{\mathrm{a}}$ \\
\hline & CYP3A/4/5 & & & & \\
\hline t1/2 elimination in healthy patients (hours) & $3.5-5.5$ & $6.9-7.3$ & $4.9-7.6$ & 5.7 & $24-64.2$ \\
\hline t1/2 elimination in cancer patients (hours) & 4 & 7.5 & $9-11$ & 8 & 128 \\
\hline
\end{tabular}

a Minor

mediated by the P450 CYP3A and CYP1A1 isoenzymes which is different from the other 5-HT3RAs. Ondansetron is $70-76 \%$ bound to plasma protein and is extensively metabolized by CYP3A4 in the liver by hydroxylation of the indole ring followed by glucuronide or sulfate conjugation. Tropisetron is metabolized mainly by the liver P450 CYP2D6 isoenzyme through oxidative hydroxylation of the indole ring followed by conjugation with glucuronic acid or sulfate which are excreted by the kidneys [15, 20].

Palonosetron is $62 \%$ bound to plasma proteins. Palonosetron's total clearance is lower than the other 5-HT3RAs resulting in a relatively long plasma elimination half life [21]. Palonosetron is metabolized mainly by CYP2D6 (50\%) and followed by CYP3A and CYP1A2 mediated metabolism [15].

Granisetron, ondansetron and palonosetron have slightly different receptor specificity. Palonosetron is a highly selective, high affinity competitive antagonist of the 5-HT3A receptor, whereas granisetron is highly specific for all subtypes of 5-HT3 receptors but has little or no affinity for 5-HT1, 5-HT2 and 5-HT4 receptors. Ondansetron also binds to the 5-HT1B, 5-HT1C, $\alpha 1$ adrenergic and $\mu$-opioid receptors. The clinical relevance of these findings is not clear [15]. Despite the fact that ondansetron has different affinity to 5-HT3B,1B,1C, $\alpha$-adrenergic and $\mu$ - opioid receptors as compared to granisetron, many studies have shown that this not imply differential efficacy between ondansetron and granisetron [13].

\section{Dopamine antagonists}

The exact mechanism of action of the dopamine antagonists prochlorperazine and metoclopramide as anti-emetic drugs is unclear, but prochlorperazine inhibits apomorphine induced vomiting by blocking dopamine D2 receptors [DRD2] in the CTZ. Also metoclopramide has shown to directly affect the CTZ in the area postrema by blocking DRD2. The drug increases the CTZ threshold and decreases the sensitivity of visceral nerves that transmit afferent impulses from the gastrointestinal tract to the vomiting center in the lateral reticular formation [22].

The phenothiazine derivative prochlorperazine is primarily metabolized in the liver via hydroxylation, oxidation, demethylation, sulfoxide formation and conjugation with glucuronic acid. The oxidative reactions are catabolized by CYP2D6. Metoclopramide is also metabolized by the liver and its metabolites are excreted in the urine and feces [22, 23]. CYP2D6 plays a major role in metoclopramide metabolism, thus poor metabolizer of CYP2D6 may have slower elimination of metoclopramide [24]. Also the buthyrophenone haloperidol shows extensive hepatic metabolism with CYP3A4 being the main enzyme involved, [25, 26].

\section{Corticosteroids}

Corticosteroids such as dexamethasone are potent antiemetics and are used in combination with other agents. Their anti-emetic mechanism of action is uncertain but it is assumed that it involves inhibition of the prostaglandin synthesis in the hypothalamus [26].

Corticosteroids are metabolized in most tissues, but primarily in the liver through glucuronidation and sulfoxidation pathways to biologically inactive compounds [22]. Dexamethasone and methylprednisolon are substrates of CYP3A4 [13].

\section{Benzodiazepines}

The anti-emetic mechanism of action of benzodiazepines, for example lorazepam, is related to the combination effects of sedation, reduction in anxiety, and possibly depression of the vomiting centre [22, 26].

Benzodiazepines bind to plasma protein, varying from 70-99\%, and undergo extensive metabolism by CYP enzymes [27]. The CYP2C19 and CYP3A4/5, CYP2C9 and CYP1A2 contribute to the metabolism of benzodiazepines. 


\section{Cannabinoids}

Cannabinoids have an anti-emetic effect at the enterochromaffin cells in the gastrointestinal tract and an anticholinergic effect on cholinergic terminals and Auerbach's plexus and possibly mediate the prostaglandin cyclic nucleotide system [26]. Two cannabinoid drugs, dronabinol and nabilone, have been approved for CINV. Although there are conflicting data, cannabinoids can be used for refractory emesis [23, 28, 29]. Nabilone showed superior efficacy compared to prochlorperazine and also the combination of the two agents were better than was used alone [30]. The use of these agents is limited because of their slow elimination from the body and because of adverse effects such as sedation, dysphoria, vertigo, euphoria, dizziness, and dry mouth [29]. Cannabinoids are prone to pharmacodynamic and/or pharmacokinetic interactions with other drugs. The interaction of cannabinoids with chemotherapeutic agents that are sensitive to the alteration of CYP3A function should be closely monitored [31].

\section{Antihistamines}

The pharmacological effect of the anti-emetic drug dimenhydrinate is conceived as result of its diphenhydramine moiety. Dimenhydrinate and meclizine have CNS depressant, anti-cholinergic, anti-emetic, antihistamines and local anesthetic effects. Although its anti-emetic mechanism of action is unclear, dimenhydrinate has been shown to inhibit vestibular stimulation, acting first on the otolith system and in larger doses on the semicircular canals. Dimenhydrinate inhibits acetylcholine and it is proposed that this is the primary mechanism of action. Dimenhydrinate is widely distributed into body tissues, and is metabolized by the liver via CYP450, but limited information is available on which specific isoenzyme is involved [22].

\section{Neurokinin-1 antagonist}

Aprepitant is a neurokinin-1 receptor antagonist and inhibits the action of substance $\mathrm{P}$ in the emetic pathways both centrally and peripherally. Substance P, neurokinin-A (NK-A) and neurokinin-B (NK-B) are members of the tachykinin family. These peptides are mediated through three receptors: NK-1, NK-2, NK-3. Substance P displays the strongest affinity for NK-1, whereas NK-A and NK-B have strong affinity for NK-2 and NK-3 [32]. Recently, substance $\mathrm{P}$ has shown to have a role in emesis, especially in delayed emesis [33].

Aprepitant is highly bound to plasma proteins ( $>95 \%)$ and has an elimination half life of $9-13 \mathrm{~h}$ making it suitable for once daily administration. Aprepitant is both a substrate and a moderate inhibitor of CYP3A4. In addition, aprepitant also induces CYP2C9 and CYP3A4 and therefore may be prone to drug-drug interactions [32].

Casopitant, a new yet unapproved neurokinin- 1 receptor antagonist, has an oral clearance of $24.4 \mathrm{~L} / \mathrm{h} / \mathrm{kg}$ in female patients and this agent is both a substrate and weak to moderately inhibitor of CYP3A4 [34].

Variable efficacy of anti-emetics

According to the guideline of the American Society of Clinical Oncology on prevention of CINV, the combination of neurokinin-1 receptor antagonist, 5-HT3RA and dexamethasone is the regimen of choice in patients receiving highly emetogenic chemotherapy. Moreover, addition of lorazepam or alprazolam, or substitution the 5-HT3RA with high dose intravenous of metoclopramide or adding dopamine antagonist is recommended in patients with suboptimal response [7, 8].

\section{5-Hydroxytryptamine 3 receptor antagonists [5-HT3RAs]}

The use of 5-HT3RAs and the combination with dexamethasone results in complete acute emesis protection in $70 \%$ of patients receiving a first cycle of highly emetogenic chemotherapy. However, they are not very effective in the delayed phase of emesis. Indeed, even following complete protection in the acute phase, $40 \%$ of patients experience delayed symptoms of emesis, which interfere with quality of life. In the outpatients setting, the symptoms may be underestimated by health care professionals [2].

Tropisetron, ondansetron and granisetron are considered to have similar efficacy which is supported by several clinical studies. A Turkish study showed that the complete response rate of these drugs in combination with dexamethasone in the control of acute emesis was $80 \%$ for tropisetron $72 \%$ for ondansetron and $72 \%$ for granisetron $(P=0.877)$. These three drugs also appeared to have similar side-effect profiles [35].

Palonosetron was found to be effective in preventing delayed CINV and it was approved by FDA as the first anti-emetic drug for preventing both acute and delayed CINV [10]. It has a higher binding affinity and longer elimination half life as compared to the other 5-HT3RAs due to its unique structural characteristics based on a fused tricyclic ring system [36, 37]. The use of palonosetron, aprepitant and dexamethasone as a single day regimen of anti-emetic combination in cancer patients receiving cyclophosphamide and/or doxorubicin resulted in complete protection in $51 \%$ of patients with $76 \%$ of patients in acute phase and $66 \%$ of patients in delayed phase of emesis [38]. The use of this combination in Japanese patients showed protection in $75 \%$ of patients in the acute phase compared 
with $73 \%$ in the granisetron group. During the delayed phase $57 \%$ of patients had complete response in the palonosetron group compared to $45 \%$ of patients in granisetron group [39].

Ramosetron and azasetron are the newest agents of 5-HT3RA. In cancer patients receiving highly and moderately emetogenic chemotherapy, the combination of intravenous ramosetron and dexamethasone showed $77 \%$ of complete response in comparison with granisetron and dexamethasone which had $82 \%$ of complete response [40].

Azasetron, in combination with olanzapine and dexamethasone could improve the complete antiemetic response of cancer patients in the delayed phase. In this study the combination of azasetron -dexamethasone and olanzapine-azasetron-dexamethasone was compared in patients receiving highly and moderately emetogenic chemotherapy [41].

\section{Dopamine antagonists}

Metoclopramide is still used for breakthrough CINV symptoms and as adjunctive medications in building antiemetic regimens for patients with refractory nausea and vomiting. Prochlorperazine has similar efficacy as ondansetron plus dexamethasone in preventing delayed nausea vomiting on days 2-5 [42]. However, the use of metaclopramide in pediatric and elderly patients is not recommended because of the high incidence of dystonic reactions $[8,43]$.

\section{Corticosteroids}

The complete response rates of dexamethasone are about 15-20\% higher when it was added to 5-HT3RAs. Dexamethasone is effective in prevention of CINV in both the acute phase and delayed phase. Corticosteroids are sometimes underutilized because of their potential adverse effects. Because the anti-emetic use of corticosteroids is short term, tapering the dose is rarely needed [29].

\section{Benzodiazepines}

Benzodiazepines, especially lorazepam are being used for patients with breakthrough symptoms and anticipatory symptoms of CINV [8, 23]. Olanzapine can improve both patients' quality of life and patients' complete response in delayed nausea vomiting during the treatment of highly or moderate emetogenic cytostatics [41]. In a phase II study, the combination of olanzapine, dexamethasone and palonosetron was effective in controlling acute nausea and vomiting in patients receiving highly and moderately emetogenic cytostatics [44].

\section{Cannabinoids}

Nabilone as anti-emetic was superior to placebo, domperidone and prochlorperazine in preventing CINV, but not superior not metoclopramide or chlorpromazine. Nabilone also did not increase the benefit of 5-HTRAs as anti-emetic in CINV [45]. The use of cannabinoids and olanzapine have been suggested as potentially useful interventions, but data from phase III clinical trials are still lacking [46].

\section{Antihistamines}

Diphenhydramine or hydroxyzine in the prevention of CINV have not shown any anti-emetic activity. Antihistamines have a role in the treatment of nausea thought to be mediated by the vestibular system [3].

\section{NK-1 antagonist}

There is evidence to support the use of a three-drug regimen for prevention of acute emesis in highly emetic regimens as a minimum standard of care, including a 5-HT3RA, a neurokinin-1 antagonist (NK-1A) and dexamethasone [10,11]. A randomised phase II study of the NK-1 antagonist aprepitant in patients receiving cisplatin showed a complete protection in the NK-1 antagonist arm of the study of $93 \%$ for acute emesis and $83 \%$ for delayed emesis compared to $67 \%$ for acute emesis and $37 \%$ of delayed emesis with granisetron and dexamethasone. The addition of aprepitant to the 5-HT3RA and dexamethasone can improve the acute emesis protection by a further $10-15 \%$ and $20-30 \%$ in the delayed phase of emesis [19].

The efficacy of casopitant was shown in study comparing the combination of casopitant-ondansetron-dexamethasone and ondansetron-dexamethasone. The addition of casopitant could increase the complete antiemetic response at $120 \mathrm{~h}$ by $20 \%$ in cancer patients receiving highly emetogenic chemotherapy [47].

Aprepitant is not available in some countries, and the 5-HT3RAs are relatively expensive and may therefore not be an option for some patients. Other agents such as prochlorperazine, nabilone, dronabinol and olanzapine may be added, however no studies are available on the efficacy and safety of these combinations [46].

\section{General remark concerning variable clinical efficacy of anti-emetic drugs}

The effectivity of anti-emetic treatment is also influenced by factors such as age of the patients, history of alcohol intake, type of cancer, chemotherapy regimen and course of chemotherapy. There are data available from gynaecological cancer patients showing that younger patients who 
received cisplatin regimen experience significant lower rates of nausea and vomiting complete responses. However, patients with the first three course of chemotherapy had significant higher complete response with regard to nausea than those with chemotherapy after the third course [48]. The 5-HT3RAs with long duration of action, low risk of drug-drug interactions and once daily dosing are preferred [49]. Combination of palonosetron and dexamethasone shows no significant differences in complete response and complete control of emesis in elderly patients $(\geq 65$ years) as compared to non-elderly patients ( $<65$ years) who received high and moderate emetogenic cytostatic agent $(P=1.00)$ [50]. In cancer patients with multiple-day chemotherapy, the efficacy of the combination of palonosetron and dexamethasone is not significantly different compared to ondansetron and dexamethasone in prevention of delayed emesis. Nevertheless, patients still need rescue anti-emetic treatment to a considerable extent [37]. Female gender and a history of motion sickness is positively related to efficacy to prevent nausea in patients receiving combination of 5HT3RA and dexamethasone. In addition, patients with a history of low chronic alcohol intake experienced more post chemotherapy vomiting [51].

\section{Pharmacogenetic studies of anti-emetics}

Differential responses of patients to anti-emetic drugs can be due to factors such as age, gender, and variations in the activity of enzymes, which are involved in the uptake, binding, activation or degradation of these drugs. Table 1 summarizes the published pharmacogenetic studies of antiemetics. The pharmacogenetic studies about DRD2 antagonists related with their usage as anti-emetics are not found. No pharmacogenetic studies on corticosteroids used as anti-emetic are known.

\section{Pharmacogenetic studies exploring variation in genes encoding drug receptors}

Tremblay et al. [52] performed a pharmacogenetic study in German Caucasian cancer patients $(n=242)$, who received moderately to highly emetogenic cytostatic drug regimens. Prophylactic tropisetron or ondansetron during chemotherapy was given to the patients. In total, 13 polymorphisms in the 5-HT3B receptor gene were studied and the frequencies of these variants ranged from 0.4 to $0.7 \%$. Homozygotes for the -100_-102AGG deletion variant in the promoter region of 5-HT3B receptor gene experienced significantly more vomiting and nausea. Patients homozygous for the -100_-102AGG deletion variant of the 5-HT3B receptor gene showed the highest intensity of vomiting and nausea after chemotherapy, whereas the patients having the wild type showed the lowest score [mean value of episodes of vomiting in the first observation period of $1 \pm 0.58$ vs. $0.23 \pm 0.07 ; P=0.02]$. The intensity of vomiting of heterozygous carriers of the deletion variant was in between the intensity of vomiting observed in the homozygous mutant and the wild type carriers. The Odds Ratio (OR) for nausea and vomiting was 0.5 [95\% CI: $0.1-3.2]$ in the heterozygous carriers of the deletion variant and 32 in homozygous carriers of the deletion variant [95\% CI: 2.5-422) after adjustment for the other predictors of nausea and vomiting, such as age, female gender, glucocorticoids usage, and the variant of CYP2D6. However, the frequency of the heterozygous genotype for the deletion variant is approximately $20 \%$ whereas the frequency of the homozygous genotype is only $1.3 \%$. Moreover, the data warrant confirmation with larger sample sizes.

Kaiser et al. [6], investigated polymorphisms of the 5-HT3A receptor in 242 Caucasian cancer patients with various emetogenic treatments. They included 21 polymorphisms with an allele frequency of the variant ranging from 0.2 to $31.1 \%$ in their study. The number of patients suffering from nausea was $35.9 \%$ and higher than the number of patients with emesis $(23.7 \%)$. No significant association between efficacy and genetic variants was found. Only patients with the heterozygous Met257Ile polymorphism showed a non-significantly lower intensity of nausea and vomiting compared to wild type patients. However, the frequency of the Met257Ile variant is very low and there was no single individual homozygous for the Met allele. The $5819 \mathrm{G}>$ A polymorphism showed a nonsignificant higher intensity of nausea and vomiting compared to patients homozygous for the $\mathrm{G}$ allele. The authors suggest to consider a combination of individual risk factors such as age, gender, the emetogenicity level of cytotoxic drug and the polymorphism of CYP2D6, as a predictor of emesis risk while a single genetic polymorphism in the 5-HT3A receptor gene may not serve as a pharmacogenetic predictor of anti-emetic treatment with 5-HT3RAs in cancer patients [6].

A study on polymorphisms of the 5-HT3C receptor gene in 70 Caucasian cancer patients receiving dolasetron or ondansetron was performed by Ward et al. [53]. The study revealed seven novel variants in the 5-HT3C gene with allele frequencies ranging from 1.4 to $42.9 \%$. The common polymorphisms were $6342 \mathrm{C}>\mathrm{T}, \quad 7051 \mathrm{G}>\mathrm{A}$ and $7142 \mathrm{G}>\mathrm{C}$. There were no statistically significant associations between either isolated variants or haplotypes and anti-emetic efficacy. About $18.6 \%$ of patients failed to achieve the optimal protection and $28.6 \%$ of patients experienced nausea. This study concluded that genetic variants of the 5-HT3C receptor genes may not be predictive for anti-emetic response of the used drugs .

Fasching et al. [54] studied 120 Caucasian cancer patients receiving a combination of ondansetron- 
dexamethasone before anthracycline chemotherapy. They explored 1 SNP in 5-HT3B receptor gene (Y129S) and 2 SNPs in 5-HT3C receptor gene (A405G and K163 N) with an allele frequency ranging from 29.9 to $62.1 \%$. The Y129S and A405G showed no significant association with the complete response of emesis. However the K163 N variant was found to be significantly associated with a higher percentage of non responders. Wild type and heterozygous patients were reported to have a vomiting episode rate of $22 \%$, whereas homozygous patients were reported to have a vomiting episode in $50 \%$ of the patients. The homozygous variants of K163 $\mathrm{N}$ had hazard ratio of 3.35 (95\% CI: 1.00-11.25) in comparison with the heterozygous patients in acute emesis. Therefore, the HTR3C gene could serve as a predictive factor for CINV in patients undergoing moderately emetogenic chemotherapy.

\section{Pharmacogenetic studies exploring variation in genes encoding enzymes involved in drug metabolism}

The highly polymorphic cytochrome $\mathrm{P} 450$ mono-oxygenase system in the liver is involved in the metabolism of many drugs. About 20 to $25 \%$ of all drugs in clinical use are metabolized at least in part by CYP2D6 [55]. CYP2D6 activity may be classified into one of four categories: (1) poor metabolizers (PM), (2) intermediate metabolizers (IM), (3) extensive metabolizers (EM), (4) ultrarapid metabolizers (UM) [52]. The majority of the Caucasian population is classified into EM, 5-10\% are PM, approximately $2 \%$ are UM whereas less than $2 \%$ of Asians were found to be PM and more than $50 \%$ were found to be EM $[15,53]$. The frequency of dysfunctional CYP2D6 alleles in Asians is $50 \%$ and higher than in Caucasians (29\%). Therefore, many Asians, including Japanese, Chinese and Malay, metabolize CYP2D6 mediated drugs more slowly than Caucasians, because of predominantly CYP2D6*10, a highly frequent reduced function allele. Kaiser et al. [20] studied the clinical impact of genetic polymorphisms in the CYP2D6 gene on 5-HT3RAs response in cancer patients. Caucasian patients who were UMs had more vomiting within the first 4 -h $(P=0.001)$ and within the $5-24 \mathrm{~h}$ period $(P=0.03)$ when given ondansetron and tropisetron as prophylactic therapy. This result was supported by the observation that tropisetron is primarily dependent on the CYP2D6 isoenzyme for metabolism. The frequency of UMs in Caucasians is low (1.5\%) and the study must be confirmed with larger sample sizes to define the contribution of genotyping.

In a study investigating patients' response to ondansetron prophylaxis for post-operative nausea and vomiting $(n=250)$, there were significant differences of vomiting incidence in PM, IM, EM and $\mathrm{UM}(8,17,15$ and $45 \%$, $P<0.01)$ but not in nausea incidence [56].
Variation in genes encoding drug transporters

A study in cancer patients $(n=216)$ receiving high or moderate emetogenic cytostatic drugs which were given prophylactic tropisetron, ondansetron or granisetron was performed to explore an association of $A B C B 1$ $3435 C>T$ polymorphism with clinical resistance to 5-HT3RAs. Overall the proportion of patients who were protected from nausea and vomiting was about $60 \%$ in the acute phase and $50 \%$ in the delayed phase of chemotherapy. Patients who were homozygous for the ABCB1 $3435 T$ allele responded better to anti-emetic therapy [92.9\%] compared with individuals who were heterozygous $(56.1 \%)$ or homozygous for the $A B C B 13435 C$ allele (47.6\%) in the acute phase $(P=0.044)$. This difference reached statistical significance in the granisetron-treated group. However, no statistically significant differences were found in the patients treated with tropisetron or ondansetron, which is surprising since ondansetron is known to be transported by $\mathrm{ABCB} 1$ whereas tropisetron is not. It is likely that patients with the TT genotype accumulate higher concentrations of 5-HT3RAs in the brain and may benefit more from 5-HT3RA treatment. During the delayed phase of chemotherapy, there were no differences in the proportion of complete control of emesis across the genotype groups $(P=0.53)$. The findings of this study need to be confirmed in a cohort treated with a more homogeneous chemotherapeutic regimen and at a larger sample size [57].

\section{Conclusion}

Despite a wide armamentarium of antiemetic drugs a considerable number of cancer patients treated with emetogenic chemotherapy experience nausea and vomiting. Pharmacogenetics may help to individualize anti-emetic treatment however this field is relatively unexplored. Interestingly, drug transporters, metabolism and receptor target pathways of 5HT3RAs are known to be polymorphic and have shown to be related to efficacy of 5-HT3RAs. However, it is too early to implement the results of the various studies into clinical practice. Additional large studies also considering non-genetic risk factors are warranted.

Funding This review was supported by the Netherlands Organization for International Cooperation in Higher Education (Nuffic).

Conflicts of interest No conflicts of interest to declare.

Open Access This article is distributed under the terms of the Creative Commons Attribution Noncommercial License which permits any noncommercial use, distribution, and reproduction in any medium, provided the original author(s) and source are credited. 


\section{References}

1. Naeim A, Dy SM, Lorenz KA, Sanati H, Walling A, Asch SM. Evidence-based recommendations for cancer nausea and vomiting. J Clin Oncol. 2008;26:3903-10.

2. Schnell F. Chemotherapy-induced nausea and vomiting: the importance of acute antiemetic control. Oncologist. 2003;8(2): 187-98.

3. Jordan K, Kasper C, Schmoll HJ. Chemotherapy-induced nausea and vomiting: current and new standards in the antiemetic prophylaxis and treatment. Eur J Cancer. 2005;41:199-205.

4. Ballatori E, Roila F, Ruggeri B, Betti M, Sarti S, Soru G, et al. The impact of chemotherapy-induced nausea and vomiting on health-related quality of life. Support Care Cancer. 2007;15: 179-85.

5. de Wit R, Aapro M, Blower PR. Is there a pharmacological basis for differences in 5-HT3-receptor antagonist efficacy in refractory patients? Cancer Chemother Pharmacol. 2005;56:231-8.

6. Kaiser R, Tremblay PB, Sezer O, Possinger K, Roots I, Brockmoller J. Investigation of the association between 5-HT3A receptor gene polymorphisms and efficiency of antiemetic treatment with 5-HT3 receptor antagonists. Pharmacogenetics. 2004; $14: 271-8$

7. Roila F, Hesketh PJ, Herrstedt J. Prevention of chemotherapyand radiotherapy-induced emesis: results of the 2004 Perugia International Antiemetic Consensus Conference. Ann Oncol. 2006;17:20-8.

8. Kris MG, Hesketh PJ, Somerfield MR, Feyer P, Clark-Snow R, Koeller JM, et al. American Society of Clinical Oncology guideline for antiemetics in oncology: update 2006. J Clin Oncol. 2006;24:2932-47.

9. Hesketh PJ. Defining the emetogenicity of cancer chemotherapy regimens: relevance to clinical practice. Oncologist. 1999;4: 191-6.

10. Rubenstein EB, Slusher BS, Rojas C, Navari RM. New approaches to chemotherapy-induced nausea and vomiting: from neuropharmacology to clinical investigations. Cancer J. 2006;12:341-7.

11. Rang H, Dale M, Ritter J, Flower R. Pharmacology. 6 th, 391. 2007. Elsevier. ISBN: 9780443050473.

12. Hesketh PJ. Chemotherapy-induced nausea and vomiting. N Engl J Med. 2008;358:2482-94.

13. Herrstedt J, Dombernowsky P. Anti-emetic therapy in cancer chemotherapy: current status. Basic Clin Pharmacol Toxicol. 2007;101:143-50.

14. Johnston KD. The potential for mu-opioid receptor agonists to be anti-emetic in humans: a review of clinical data. Acta Anaesthesiol Scand. 2010;54:132-40.

15. Ho KY, Gan TJ. Pharmacology, pharmacogenetics, and clinical efficacy of 5-hydroxytryptamine type 3 receptor antagonists for postoperative nausea and vomiting. Curr Opin Anaesthesiol. 2006;19:606-11.

16. Niesler B, Kapeller J, Hammer C, Rappold G. Serotonin type 3 receptor genes: HTR3A, B, C, D, E. Pharmacogenomics. 2008;9: 501-4.

17. Herrstedt J. Antiemetic research: a look to the future. Support Care Cancer. 1998;6:8-12.

18. Blower PR. 5-HT3-receptor antagonists and the cytochrome P450 system: clinical implications. Cancer J. 2002;8:405-14.

19. de Wit R. Current position of 5HT3 antagonists and the additional value of NK1 antagonists; a new class of antiemetics. Br J Cancer. 2003;88:1823-7.

20. Kaiser R, Sezer O, Papies A, Bauer S, Schelenz C, Tremblay PB, et al. Patient-tailored antiemetic treatment with 5-hydroxytryptamine type 3 receptor antagonists according to cytochrome P-450 2D6 genotypes. J Clin Oncol. 2002;20:2805-11.
21. Stoltz R, Cyong JC, Shah A, Parisi S. Pharmacokinetic and safety evaluation of palonosetron, a 5-hydroxytryptamine-3 receptor antagonist, in US and Japanese healthy subjects. J Clin Pharmacol. 2004;44:520-31.

22. McEvoy GK. AHFS Drug Information. 2299, 2798,2800, 2850. 2004. American Society of Health System Pharmacist, Bethesda. ISBN: 1585280585.

23. Page C, Curtis M, Sutter M, Walker M, Hoffman B. Integrated Pharmacology. London: Mosby International, 2002. ISBN: 978-0723432210.

24. Desta Z, Wu GM, Morocho AM, Flockhart DA. The gastroprokinetic and antiemetic drug metoclopramide is a substrate and inhibitor of cytochrome P450 2D6. Drug Metab Dispos. 2002;30: 336-43.

25. Kudo S, Ishizaki T. Pharmacokinetics of haloperidol: an update. Clin Pharmacokinet. 1999;37:435-56.

26. Herfindall E, Gourley D. Textbook of therapeutics, drug and disease management. Philadelphia: Lippincott Williams \& Wilkins; 2000. ISBN: 9780781724159.

27. Williams D, Lemke T. Foye's principal of medicinal chemistry. Baltimore: Lippincott Williams \& Wilkins; 2002. ISBN: 978-0683 307375.

28. Onaivi ES, Ishiguro H, Gong JP, Patel S, Meozzi PA, Myers L, et al. Functional expression of brain neuronal CB2 cannabinoid receptors are involved in the effects of drugs of abuse and in depression. Ann N Y Acad Sci. 2008;1139:434-49.

29. Lohr L. Chemotherapy-induced nausea and vomiting. Cancer J. 2008;14:85-93.

30. Slatkin NE. Cannabinoids in the treatment of chemotherapyinduced nausea and vomiting: beyond prevention of acute emesis. J Support Oncol. 2007;5:1-9.

31. de Jong FA, Engels FK, Mathijssen RH, van ZL, Verweij J, Peters RP, et al. Medicinal cannabis in oncology practice: still a bridge too far? J Clin Oncol. 2005;23:2886-91.

32. Patel L, Lindley C. Aprepitant-a novel NK1-receptor antagonist. Expert Opin Pharmacother. 2003;4:2279-96.

33. Flemm LA. Aprepitant for chemotherapy-induced nausea and vomiting. Clin J Oncol Nurs. 2004;8:303-6.

34. Ruhlmann C, Herrstedt J. Casopitant: a novel NK(1)-receptor antagonist in the prevention of chemotherapy-induced nausea and vomiting. Ther Clin Risk Manag. 2009;5:375-84.

35. Abali H, Celik I. Tropisetron, ondansetron, and granisetron for control of chemotherapy-induced emesis in Turkish cancer patients: a comparison of efficacy, side-effect profile, and cost. Cancer Invest. 2007;25:135-9.

36. Navari RM. Antiemetic control: toward a new standard of care for emetogenic chemotherapy. Expert Opin Pharmacother. 2009; 10:629-44.

37. Musso M, Scalone R, Bonanno V, Crescimanno A, Polizzi V, Porretto F, et al. Palonosetron (Aloxi ${ }^{\circledR}$ ) and dexamethasone for the prevention of acute and delayed nausea and vomiting in patients receiving multiple-day chemotherapy. Support Care Cancer. 2008; 17:205-9.

38. Grunberg SM, Dugan M, Muss H, Wood M, Burdette-Radoux S, Weisberg T, et al. Effectiveness of a single-day three-drug regimen of dexamethasone, palonosetron, and aprepitant for the prevention of acute and delayed nausea and vomiting caused by moderately emetogenic chemotherapy. Support Care Cancer. 2009;17:589-94.

39. Saito M, Aogi K, Sekine I, Yoshizawa H, Yanagita Y, Sakai H, et al. Palonosetron plus dexamethasone versus granisetron plus dexamethasone for prevention of nausea and vomiting during chemotherapy: a double-blind, double-dummy, randomised, comparative phase III trial. Lancet Oncol. 2009;10:115-24.

40. Ho CL, Su WC, Hsieh RK, Lin ZZ, Chao TY. A randomized, double-blind, parallel, comparative study to evaluate the efficacy 
and safety of ramosetron plus dexamethasone injection for the prevention of acute chemotherapy-induced nausea and vomiting. Jpn J Clin Oncol. 2010;40:294-301.

41. Tan L, Liu J, Liu X, Chen J, Yan Z, Yang H, et al. Clinical research of Olanzapine for prevention of chemotherapy-induced nausea and vomiting. J Exp Clin Cancer Res. 2009;28:1-7.

42. Lindley C, Goodin S, McCune J, Kane M, Amamoo MA, Shord S, et al. Prevention of delayed chemotherapy-induced nausea and vomiting after moderately high to highly emetogenic chemotherapy: comparison of ondansetron, prochlorperazine, and dexamethasone. Am J Clin Oncol. 2005;28:270-6.

43. Avorn J, Gurwitz JH, Bohn RL, Mogun H, Monane M, Walker A. Increased incidence of levodopa therapy following metoclopramide use. JAMA. 1995;274:1780-2.

44. Navari RM, Einhorn LH, Loehrer PJ Sr, Passik SD, Vinson J, McClean J, et al. A phase II trial of olanzapine, dexamethasone, and palonosetron for the prevention of chemotherapy-induced nausea and vomiting: a Hoosier oncology group study. Support Care Cancer. 2007;15:1285-91.

45. Davis MP. Oral nabilone capsules in the treatment of chemotherapy-induced nausea and vomiting and pain. Expert Opin Investig Drugs. 2008;17:85-95.

46. Warr DG. Chemotherapy- and cancer-related nausea and vomiting. Curr Oncol. 2008;15:S4-9.

47. Grunberg SM, Rolski J, Strausz J, Aziz Z, Lane S, Russo MW, et al. Efficacy and safety of casopitant mesylate, a neurokinin 1 (NK1)-receptor antagonist, in prevention of chemotherapyinduced nausea and vomiting in patients receiving cisplatin-based highly emetogenic chemotherapy: a randomised, double-blind, placebo-controlled trial. Lancet Oncol. 2009;10:549-58.

48. Pradermdee P, Manusirivithaya S, Tangjitgamol S, Thavaramara T, Sukwattana P. Antiemetic effect of ondansetron and dexamethasone in gynecologic malignant patients receiving chemotherapy. J Med Assoc Thai. 2006;89(Suppl 4):S29-36.

49. Aapro M, Johnson J. Chemotherapy-induced emesis in elderly cancer patients: the role of 5-HT3-receptor antagonists in the first 24 hours. Gerontology. 2005;51:287-96.

50. Massa E, Astara G, Madeddu C, Dessi M, Loi C, Lepori S, et al. Palonosetron plus dexamethasone effectively prevents acute and delayed chemotherapy-induced nausea and vomiting following highly or moderately emetogenic chemotherapy in pre-treated patients who have failed to respond to a previous antiemetic treatment: comparison between elderly and non-elderly patient response. Crit Rev Oncol Hematol. 2009;70:83-91.

51. Osoba D, Zee B, Pater J, Warr D, Latreille J, Kaizer L. Determinants of postchemotherapy nausea and vomiting in patients with cancer. Quality of Life and Symptom Control Committees of the National Cancer Institute of Canada Clinical Trials Group. J Clin Oncol. 1997;15:116-23.

52. Tremblay PB, Kaiser R, Sezer O, Rosler N, Schelenz C, Possinger $\mathrm{K}$, et al. Variations in the 5-hydroxytryptamine type $3 \mathrm{~B}$ receptor gene as predictors of the efficacy of antiemetic treatment in cancer patients. J Clin Oncol. 2003;21:2147-55.

53. Ward MB, Kotasek D, McKinnon RA. Investigation of HTR3C mutations for association with $5 \mathrm{HT}(3)$ receptor antagonist antiemetic efficacy. Pharmacogenomics. 2008;9:1027-33.

54. Fasching PA, Kollmannsberger B, Strissel PL, Niesler B, Engel J, Kreis $\mathrm{H}$, et al. Polymorphisms in the novel serotonin receptor subunit gene HTR3C show different risks for acute chemotherapy-induced vomiting after anthracycline chemotherapy. J Cancer Res Clin Oncol. 2008;134:1079-86.

55. Zanger UM, Raimundo S, Eichelbaum M. Cytochrome P450 2D6: overview and update on pharmacology, genetics, biochemistry. Naunyn Schmiedebergs Arch Pharmacol. 2004;369:23-37.

56. Candiotti KA. The impact of pharmacogenomics on postoperative nausea and vomiting: do CYP2D6 allele copy number and polymorphisms affect the success or failure of ondansetron prophylaxis? J Symp Pharmacogenomics. 2005;102(3):543-9.

57. Babaoglu MO, Bayar B, Aynacioglu AS, Kerb R, Abali H, Celik I, et al. Association of the ABCB1 3435C $>\mathrm{T}$ polymorphism with antiemetic efficacy of 5-hydroxytryptamine type 3 antagonists. Clin Pharmacol Ther. 2005;78:619-26.

58. Golan D, Tashjian A, Armstrong E, Galanter J, Armstrong A, Arnaout R, et al. Principles of Pharmacology, the Pathophysiology of Drug Therapy. Philadelphia: Lippincott Williams \& Wilkins; 2005. ISBN:0781783550.

59. Dimmitt DC, Choo YS, Martin LA, Arumugham T, Hahne WF, Weir SJ. Intravenous pharmacokinetics and absolute oral bioavailability of dolasetron in healthy volunteers: part 1 . Biopharm Drug Dispos. 1999;20:29-39. 